日本農薬学会誌 23, 444-445 (1998)

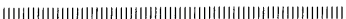
IX ICPC 特別記事

||||||||||||||||||||||||||||||||||||||||||||||||||||||||||||||||||||||||||

\title{
Topic 3
}

\section{Natural Products}

\section{京都大学農学部 上野 民夫 \\ 茨城大学農学部 児玉 治 \\ 科学技術振興事業団 田母神 繁}

Topic 3 は Natural Productsに関するセクションであり，招 待講演は天然有機化合物の単離, 活性, 合成などについて 4 件 の講演があった. ポスター発表は以下の (A) から (D) のサブ セクションに分けられて発表が行われた. (A) Pesticides of Plant Origin, (B) Microbial Pesticides, (C) Synthesis, (D) Chemistry of Biocontrol and for IPM, (E) Biotechnology of Primary and Secondary Metabolites. 上記サブセクションの中で(A) Pesticides of Plant Origin での発表数が Natural Products 全体 の約 4 割を占め, 研究発表内容は天然生理活性物質の単離と構 造決定に関するものが大半を占めた.

各サブセクションでの発表内容を以下に概説する. (A) Pesticides of Plant Originにおいては殺虫活性物質に関する研究発 表が圧倒的に多く, 抗菌活性, 除草活性, その他(殺線虫活性) の順で次いだ．殺虫活性物質に関する研究と一口にいっても，

GABA レセプターと生理活性物質との結合様式のような基礎 的な研究から, 殺虫活性物質を含む粗抽出物を使用した害虫駆 除の試験研究まで，かなり幅広い分野での研究結果が混在して いた。後者において数の多い点からいえば脂肪酸や精油を害虫 駆除に使用する試験研究の発表が目立った。

(B) Microbial Pesticidesにおいては抗菌活性物質の単離・精 製についての研究発表が最も多く, 次いで微生物自体を害虫駆 除や雑草防除に利用する微生物農薬, 昆虫に対する捸食阻害物 質についての順であった. 微生物農薬については雑草防除, 線 虫駆除などの効果試験の他に製剤・施用法についての発表も見 られた。

(C) Synthesisのサブセクションでは殺虫, 殺菌などの活性物 質や昆虫フェロモンの全合成研究が中心で, 植物ホルモンのア ナログ合成も幾つか発表された. 他のサブセクションでの発表 件数に比べ，このサブセクションでの件数は決して多くはな かったが, 有用な生理活性物質を示す天然物の合成は新しい合 成農薬のリード化合物発見の契機ともなりうるもので重要であ ク, 盛んな討論が行われていた。

(D) Chemistry of Biocontrol and for IPM では昆虫フェロモ ンの害虫駆除への応用や，ストレス下で植物が放出する揮発性 化合物の役割に関する化学生態学的な研究発表が盛んであっ た. 抗菌活性物質の単離やアレロパシー化合物の研究発表もこ のサブセクション含まれていた。

最後のサブセクション (E) Biotechnology of Primary and Secondary Metabolites では, 天然生理活性物質の生合成や植物 2 次代謝産物の生産制御についての研究や，植物に外来遺伝子 を導入して農産物の付加価値を高める研究発表などがあった。
後者に関しては, 例えば, 鉄吸収能やカロテノイド生合成能を 向上させたイネを作出し，栄養面での付加価值を高めたコメを 作る研究などが発表された。このサブセクションはPesticide Chemistryよりも, やや植物生理学に近いためか, 発表件数は他 のセクションに比べかなり少なかった。

以上のように概説されるこのセクションでの招待講演，ポス タ一発表の中から, 幾つかをピックアップして紹介する. (A) Pesticides of Plant Originのサブセクションでは, 害虫防除を目 的とした研究の発表が目立った。植物材料としては Neem tree (Azadirachta indica) が主で, 活性は azadirachtin 等を活性成分 とする捸食阻害である.Azadirachtin 高含有の粗抽出物の調製 法と害虫駆除への試験研究, azadirachtin の安定性向上, neem treeから得られた oil 中の azadirachtinなどの活性成分の分 離・分析法,さらには neem tree の組織培養細胞での azadirachtinの生産性向上を目的とした研究の発表があった。

(B) Microbial Pesticidesの分野で特に興味深かった研究のU とつに Anke 教授らによる strobilurin の単離構造決定の研究が あげられる. Strobilurin A に代表されるこの化合物はマッシュ ルームから単離された抗菌活性物質である。この化合物が注目 されると思われるのは, 最近ドイツの化学会社であるBASF 社 がこの strobilurin A をリード化合物にして化合物合成展開を 行い, 新しい作用機作を有する殺菌剤を開発したからである。 strobilurin A は光に対して不安定なため, 温室内試験では弱い 殺菌活性しか示さなかったものの, そのユニークな殺菌作用が 着目され，最終的には共役オレフィン部がエーテルを介した芳 香核に置き換えられたアナログである kresoxim-methyl として 開発された. Anke 教授らの strobilurin 類に関する作用機作, さ らに新規殺菌剤開発においてのリード化合物としての有用性に ついての文献発表はごく最近であるが, strobilurin A 自体の単 離・構造決定は 1978 年まで遡る（BASF 社が strobilurin A の殺 菌活性を温室内試験で見いだしたのは1983年である). Strobilurin A の活性発現部位の特定に始まり，さらに安定で高 活性な誘導体にいたるまでの経緯は部外者にとっては想像する しかないが, strobilurin A が持つ新規な作用機作（ミトコンド リアの呼吸阻害; NADH-ubiquinone-oxidoreductase $の$ 阻害) が研究開発に向けての大きな原動力であったろうと想像でき る。近年，有機合成化合物のランダムスクリーニングに新規農 薬のリード化合物を見いだそうとする傾向が強い. 天然生理活 性物質が新農薬のリード化合物になるためには，構造の新規性 に加之, 特に殺菌剂の場合には, 薬剂抵抗性との関連から作用 性の新規性が重要であろう。なお，Anke 教授らは今回の発表 で, strobilurin A, B, C, D に加え, トリテルペンの favoron, ジテルペンの tintinnadiol の単離についても紹介した.

今回の国際学会では (D) Chemistry of Biocontrol and for IPM のサブセクションにおいて, 最近日本国内でも研究発表が 増えつつある化学生態学的な立場での研究発表が幾つか見られ 
た．植物がストレスを受けると植物ホルモンであるエチレンが 発生し, 植物の成長に影響を与えたり, 脂肪酸が代謝され青臭 い揮発成分などが発生することは周知のことであるが，その香 気成分が植物と他の生物間での化学信号として機能しているこ とが明らかにされつつある. 蛾の幼虫（害虫）に摂食されたワ タやトウモロコシから揮発性化合物が放出され, その揮発性成 分がこの害虫の天敵を誘引する作用があることが見いだされて いる.アメリカUSDAのJ. H. Tumlinson 博士らは，攝食され た植物体から揮発成分の生成を引き起こす化合物を蛾の幼虫の 口内分泌液から単離・構造決定し, volicitin と命名している.こ の volicitinはリノール酸の代謝産物とグルタミン酸から成る アミド化合物である. 今後の研究がさらに進展し, volicitin 類化 合物の存在と機能の普遍性が示されることを期待したい. 他に, ストレス下に置かれた植物に起こる速やかな脂肪酸の酸化開裂 反応や含硫揮発性化合物の生成についての研究発表が見られ た. 今後, これら揮発性成分が果たす機能の解明は植物-植物, 植物-昆虫さらには植物-動物との間のケミカルコミニュケー ション解明のヒントになるかも知れない. また, 北海道大学の 田原教授らは植物と病原菌とのコミニュケーションをつかさど る活性物質の単離について興味ある研究結果を発表した。 ホウ レンソウ根腐病菌はホウレンソウの根部より侵入感染する病原 菌であり，アカザ科植物にも親和性であるが，キク科や夕デ科 の植物には感染しない. 彼らはこの罹病性の差が植物から分泌 される物質と関連すると考え, 病原菌遊走子の挙動に影響を与 える活性物質の単離を試みた。この病原菌に罹病性であるホウ レンソウなどの植物から遊走子の誘引活性を示す活性物質を単 離し, さらに他の植物からは遊走子の忌避, 静止, 興奮, など を引き起こす活性物質を単離した。この研究は新しい病害防除 の開発につながる可能性をもっていると考えられ, 応用研究に 発展することが期待される.

最後に, Natural Productsのセクションにおける招待講演の 中から, ドイツ Bayer 社の R. Hain 博士らの研究について紹介 したい. Modification of Plant Secondary Metabolism by Foreign Phytoalexin Genes と題する講演のなかで, R. Hain 博士はファ イトアレキシンとして広く知られる抗菌活性を有するストレス 化合物の生合成鍵酵素をコードした遺伝子を有用作物に導入 し，病害抵抗性作物を作出する試みを紹介した。生理活性物質 それ自体を利用するのではなく，その生産能力を利用する試み である. R. Hain 博士らは stilbene 型ファイトアレキシンの生合 成鍵酵素である stilbene synthase をコードする遺伝子をブドウ などの植物から単離し，これを夕バコ，ジャガイモ，イネなど に導入した。 その結果, これらの作物が病害抵抗性を獲得した ことを確認し，ファイトアレキシン生合成能の導入が病害抵抗
性獲得に有用であることを示した.さらに興味深いことに,ファ イトアレキシン生合成の外来遺伝子導入が病害抵抗性以外の形 質に大きな変化をもたらすことが報告された. 夕バコに stilbene synthase を導入し，これを恒常的に発現させたときに花色 や花粉管の形成に影響が見られた. Stilbene synthase を導入し たぺチュニアにおいては，草丈や花の矮化を生じ，色は白で雄 性不稔の花をつけた，花以外の器官には以上は観察されなかっ た. R. Hain 博士らは stilbene synthase の恒常的な発現により malonyl-CoA が多量に消費され, 花の色素であるフラボノイド の生合成に影響が生じたためであろうと解釈した． R. Hain 博 士らは雄性器官の形成についてもフラボノイドが重要な役割を 果たしているのではないかと推測している.この研究手法は植 物への病害抵抗性の付与以外に, 植物における 2 次代謝産物の 機能解明にも役立つかも知れない. 講演の最後に R. Hain 博士 は次の研究におけるファイトアレキシン生合成遺伝子のター ゲット酵素として,フラボンの一種である naringenin のメチル 化酵素 (naringenin-7- $O$-methyltransferase) を紹介した. Naringenin はイネファイトアレキシンの一つである sakuranetinの 生合成前駆体であり，水酸基がメチル化されて sakuranetin に 変換される. 蛇足ながらこの酵素は，〈しくも茨城大学農学部 の児玉治教授等によってイネ葉から初めて精製・アミノ酸配列 が決定された酵素である。 